\title{
The Potential Sex Determination Genes, Sox9a and Cyp19a, in Walleye Pollock (Gadus Chalcogrammus) Are Influenced by Water Temperature
}

\author{
So-Sun Kim ${ }^{1}$, David Nahm-Joon Kim ${ }^{1}$, Chang-Ju Lee ${ }^{1}$, Hae-Kyun Yoo ${ }^{2}$, Soon-Gyu Byun ${ }^{2}$, \\ Hyun-Jeong Lim ${ }^{2}$, Jin Choi ${ }^{3}$ and Jang-Su Park ${ }^{1, *(\mathbb{D})}$ \\ 1 Department of Chemistry and Chemistry Institute of Functional Materials, Pusan National University, \\ 2, Busandaehak-ro 63beon-gil, Geumjeong-gu, Busan 609-735, Korea; ssokim81@naver.com (S.-S.K.); \\ dk89kim@gmail.com (D.N.-J.K.); gd0090s@naver.com (C.-J.L.) \\ 2 East Sea Fisheries Research Institute, National Institute of Fisheries Science, 1194 Haean-ro, Yeongok-myeon, \\ Gangneung-si, Gangwon-do 25435, Korea; sealeader@korea.kr (H.-K.Y.); \\ sgbyun@korea.kr (S.-G.B.); limhj@korea.kr (H.-J.L.) \\ 3 Aquaculture management division, National Institute of Fisheries Science216, Gijanghaean-ro, Gijang-eup, \\ Gijang-gun, Busan 618-270, Korea; jchoi99@korea.kr \\ * Correspondence: jaspark@pusan.ac.kr; Tel.: +82-51-510-2294; Fax: +82-51-516-7421
}

Received: 10 June 2020; Accepted: 7 July 2020; Published: 8 July 2020

\begin{abstract}
Our aim was to study the relationship between the sex-determining genes, sox $9 a$ and cyp19a, and water temperature in Gadus chalcogrammus. We assessed the sex ratio based on the expression levels of sox $9 a$ and cyp $19 a$ at different water temperatures $\left(5,8,11\right.$, and $\left.14^{\circ} \mathrm{C}\right)$ and at different stages of walleye pollock development (embryos, larvae, and juveniles). Next, we used immature walleye pollock to assess sox $9 a$ expression in males and cyp $19 a$ and vitellogenin (VTG) expression in females at different water temperatures. Males expressed sox $9 a$ in the gonadal tissues, while females expressed cyp19a in the gonadal tissues and VTG in the blood plasma. In the first experiment, cyp $19 a$ expression was higher at $5{ }^{\circ} \mathrm{C}$ and $8{ }^{\circ} \mathrm{C}$, and sox $9 a$ expression was higher at 11 and $14{ }^{\circ} \mathrm{C}$. In the second experiment, sox $9 a$ expression remained relatively stable, but cyp $19 a$ expression decreased with increasing temperature, decreasing significantly after $14^{\circ} \mathrm{C}$. Similar patterns were also observed for VTG expression. These results indicate that lower water temperatures increase cyp $19 a$ expression, which increases the female ratio. Higher water temperatures increase sox $9 a$ expression, which increases the male ratio. Therefore, this study highlights the potential of the sex-determining genes and the influence of water temperature.
\end{abstract}

Keywords: sex determination; sox9a; cyp19a; walleye pollock; water temperature

\section{Introduction}

Walleye pollock (Gadus chalcogrammus) resides in the coastal waters of Korea and Japan, throughout the Kamchatka Peninsula and the Bering Sea and into the central coast areas of California [1]. The habitat water temperatures (in the Bering Sea) range between 1 and $10^{\circ} \mathrm{C}$, and for fertilized larvae, between 2 and $7^{\circ} \mathrm{C}[2,3]$. Rising water temperatures due to climate change have affected the walleye pollock habitats. Water temperature influences habitat selection, migration, and physiological changes in walleye pollock, including sex determination, reproduction, growth, hormonal changes, and metabolism [4-9]. Environmental factors such as the water temperature are important to sex determination $[10,11]$. Sex determination happens at an early developmental stage, and sex is determined by a combination of genetic-dependent sex determination (GSD), environment-dependent sex determination (ESD) such as temperature, density, $\mathrm{pH}$, and hypoxia, and endocrine factors [12-14]. In particular, the water 
temperature experienced during embryos development has greater influence on sex determination than the genetic makeup $[10,15]$. After individual sex has been determined, gonadal differentiation in teleosts can lead directly to sexual differentiation in males and females or to development of both in hermaphroditic species $[10,16]$. Teleost fish possess numerous sex-determination genes. In male fish, sexual differentiation is achieved by the upregulation of doublesex and mab-3-related transcription factor 1 (dmrt1), which is highly conserved. Dmrt1 acts with transcription factor SRY (Sex determining region Y)-box 9a (sox9a) in testis formation [17,18]. Members of the SRY-box (Sox)-family are important for male determination because of their roles in testis determination and cartilage formation $[19,20]$. In female fish, sexual differentiation is achieved by a positive feedback loop of cytochrome P450 aromatase (cyp19a), which involves the transcription factor forkhead box protein L2 (foxl2) [21,22]. Cytochrome P450 aromatase (cyp19a), a member of the cytochrome P450 superfamily, is important for female determination due to its role in synthesizing estrogens. Estrogens promote ovarian development and maintain female differentiation. Cyp19a has been identified in females in different animal phyla. Simpson et al. (1994) found cyp19a transcripts in human ovaries, placenta, adipose tissues and the brain [23]. In fish, cyp19a is used for steroidogenesis of the gonadal steroids, which plays a critical role in gonadogenesis.

This study aimed to investigate the expression levels of sox $9 a$ and cyp $19 a$ and the mechanisms underlying the response of these genes to different water temperatures. Prior to this study, gonadal tissues from adult fish were studied to investigate the induction of sox $9 a$ and cyp $19 a$, gonadal histological analysis, and VTG analysis in blood plasma. They were then divided into two experiments. The water temperatures studied were $5,8,11$, and $14{ }^{\circ} \mathrm{C}$. The first experiment reported the induction levels of sox $9 a$ and cyp $19 a$ in the embryos, larva, and juveniles (approximately $8-12 \mathrm{~cm}$ in length) at the different water temperatures. The second experiment investigated the induction levels of sox9a and cyp19a in immature fish (approximately $20-25 \mathrm{~cm}$ in length) to study the effects of water temperature in developed gonadal tissues (testis or ovary). The induction levels of vitellogenin (VTG) in female immature fish were also measured based on the VTG induction levels at different water temperatures, previously reported from this laboratory [24]. VTG is an egg yolk precursor that is synthesized in the liver. It is stimulated by estrogen and is rarely induced in males (though the VTG gene is present in male fish) [25]. As mentioned previously, cyp19a encodes aromatase to control estrogen synthesis, so correlation between cyp19a and VTG expression patterns in different water temperatures were compared.

To date, there have been no studies of sex determination or sex changes in walleye pollock in different water temperatures. Therefore, we suggest a potential mechanism of sexual determination based on water temperature in this report.

\section{Materials and Methods}

\subsection{Animals and Materials}

Walleye pollock (G. chalcogrammus) were obtained from the East Sea Fisheries Research Institute in Korea. Adult fish ( $3+$ years old) were held in a flow-through tank (10-ton, $4 \mathrm{~m}$ diameter and $1 \mathrm{~m}$ depth), with an ambient photoperiod and a continuous supply of filtered seawater $(10 \mu \mathrm{m}$ PREFLOW II, Cs Technofil Co. Ltd., Gyeonggi-do, Korea) at $7.5^{\circ} \mathrm{C}$. The fish were fed twice per day. Embryos were obtained from the adult fish and were hatched and grown until the immature fish stage. The sizes of the fish used in the experiment at each developmental stage are shown in Figure 1. Approximately 1000 embryos (Figure 1A) and larvae (Figure 1B), 100 juveniles (Figure 1C), and 50 immature fish (Figure 1D) were grown in 10-ton water tanks at different temperatures $(5,8,11$, and $14^{\circ} \mathrm{C}$ ). After the eggs hatched, the fish were fed (in order) rotifers, Artemia nauplius, and frozen copepods. The dissolved oxygen (DO) and $\mathrm{pH}$ were maintained at $9-10 \mathrm{mg} / \mathrm{L}$ and $7.9-8.1$, respectively. In experiment 1 , the embryos were reared for 5 days, the larva for 30 days, and the juveniles for 180 days. In experiment 2 , the immature fish were reared at $7.5^{\circ} \mathrm{C}$ for approximately 180 days and 
then transferred to the water temperature treatments for $\sim 10$ months before the experiment (Figure 1E). The experimental protocol used in this study was reviewed and approved by the National Institute of Fisheries Science-Institutional Animal Care and Use Committee (NIFS-IACUC) per the ethical procedures and scientific care guidelines (approval number: 2018-NIFS-IACUC-16). The fish were sacrificed by an anesthetic overdose (MS-222 (Sigma), 50 ppm), and the heart, brain, kidney, intestine, and liver tissues were collected and stored at $-80^{\circ} \mathrm{C}$.
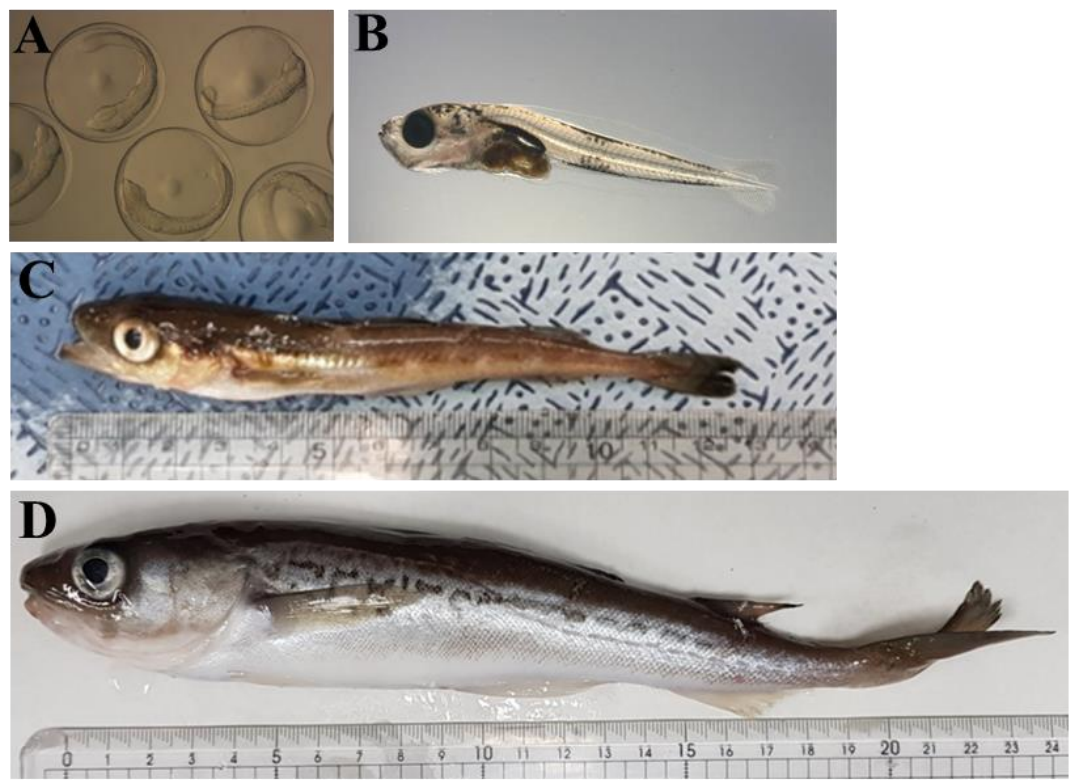

E

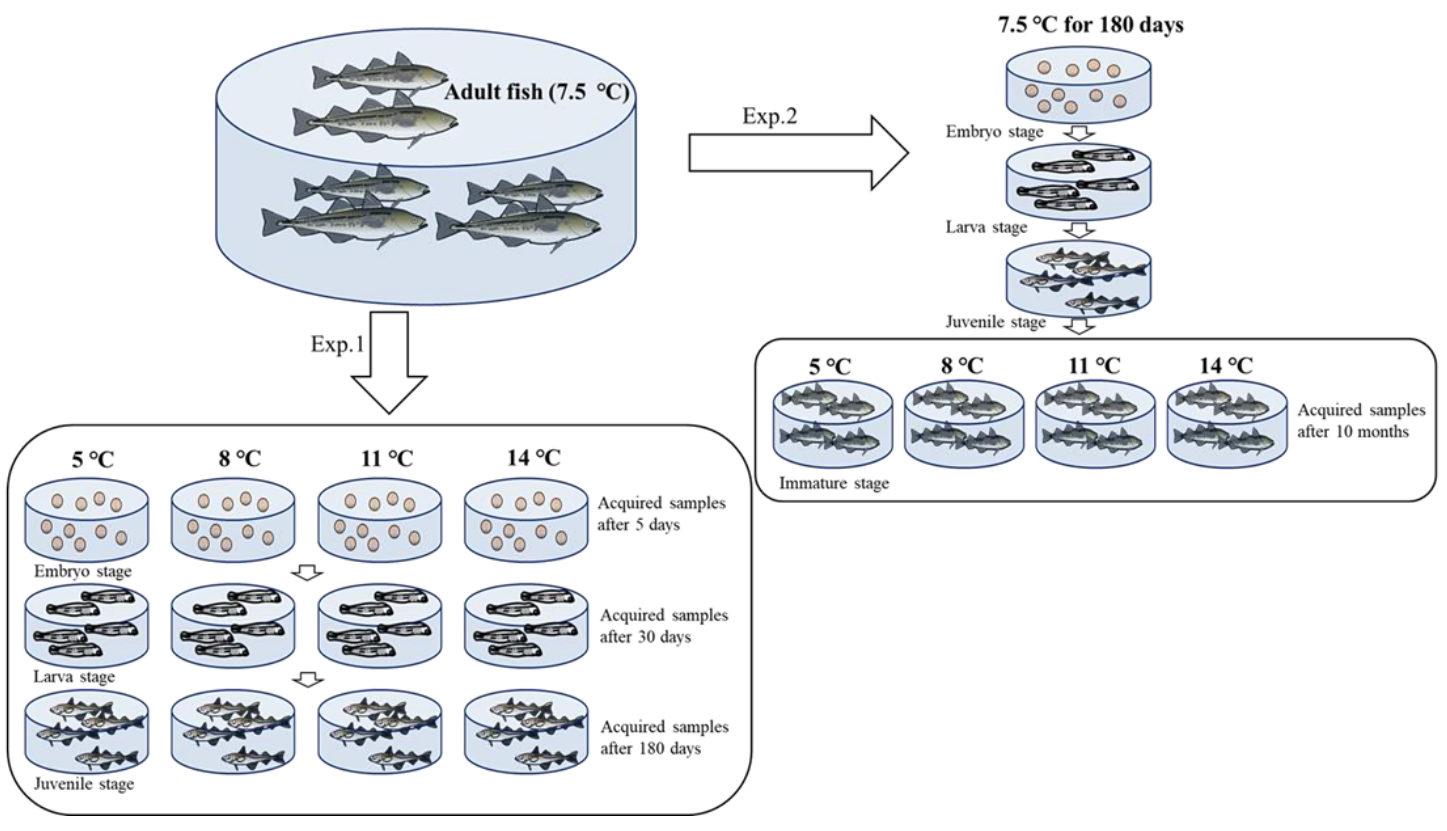

Figure 1. Walleye pollocks used in the experiment. (A) Embryos (2.5X $125 \mathrm{~h}$ after fertilization); (B) Larvae (1.6X; 30 days after hatching); (C) Juvenile fish (8-12 cm in length, approximately 180 days); (D) Immature fish (20-25 cm in length, 1+ year); (E) Schematic of the experimental samples. The fertilized eggs (Experiment 1 ) obtained from the mature (3+ years) walleye pollocks were raised in different water temperatures $\left(5,8,11\right.$, and $14{ }^{\circ} \mathrm{C}$ ). The juveniles (Experiment 2 ) were raised at $7.5^{\circ} \mathrm{C}$ for approximately 180 days before relocation to the $5,8,11$, and $14^{\circ} \mathrm{C}$ treatments, in which they were raised for 10 months. 


\subsection{Isolation of $m R N A$ Sequence}

The reverse transcriptase PCR (RT-PCR) was performed to confirm the mRNA sequences and induction levels of sox9a and cyp19a gonadal tissues (testis or ovary) in adult walleye pollock. The gonadal tissues were homogenized using liquid nitrogen and PYREX ${ }^{\circledR}$ Dounce Homogenizer Tissue Grinders (Thomas Scientific, Swedesboro, NJ, USA), and total RNA was extracted using TRIzol (Invitrogen). Only high-quality RNA (a ratio of 2.0 or higher for the absorbance at $260 \mathrm{~nm}$ and $280 \mathrm{~nm}$ ) was used in the experiment. RNA integrity was assessed by electrophoresis on $1 \%$ agarose-formaldehyde gels after staining with ethidium bromide. The single-strand cDNA was synthesized from $5 \mu \mathrm{g}$ of the total RNA with an Oligo (dT) primer by Avian Myeloblastosis Virus (AMV) Reverse Transcriptase (Promega). PCR was performed with the obtained cDNA (as a template), and $20 \mu \mathrm{M}$ of the forward primer, reverse primer, Taq DNA polymerase, and $2.5 \mu \mathrm{M}$ of each dNTP (Enzynomics, Korea). The conserved regions of the zebrafish (Danio rerio) sox9a (GenBank accession no. NM131643), Atlantic cod (Gadus morhua) sox9a (Genbank accession no. JN802288), and olive flounder (Paralichthys olivaceus) sox9a (GenBank accession no. KY924902) were used to design the primers. The cyp19a primers were designed from the conserved regions of the Atlantic cod (Gadus morhua) cyp19a (GenBank accession no. JJN802290), Sweetfish (Plecoglossus altivelis) cyp19a (Genbank accession no. KF296362), and common carp (Cyprinus carpio) cyp19a (GenBank accession no. DQ534411). All the primers were designed in the 'Primer $3^{\prime}$ program, and Table 1 presents the primer sequences used in the experiments. The PCR conditions were 30 cycles at $94^{\circ} \mathrm{C}$ for $30 \mathrm{~s}, 52{ }^{\circ} \mathrm{C}$ for $50 \mathrm{~s}$, and at $72{ }^{\circ} \mathrm{C}$ for $1 \mathrm{~min}$. Electrophoresis was used to evaluate the PCR products before insertion into a TA vector (Enzynomics, Korea) and cloning. The PCR products were evaluated by electrophoresis, and the nucleotide sequences were determined on a 3730xl DNA analyzer (Cosmogentec, Korea). The sox9a and cyp19a fragments were registered in GenBank (GenBank accession no. MT350342 and MT350341, respectively).

Table 1. Primer lists.

\begin{tabular}{clc}
\hline Primer Name & \multicolumn{1}{c}{ Sequence $\left(5^{\prime} \rightarrow \mathbf{3}^{\prime}\right)$} & Size $\mathbf{( b p )}$ \\
\hline RT-PCR $\operatorname{sox} 9 a \mathrm{~F}$ & GAGACTTCAAGAAGGACG & \multirow{2}{*}{$260 \mathrm{bp}$} \\
RT-PCR $\operatorname{sox} 9 a \mathrm{R}$ & CTTCGTTGAGGAGTCTCC & \\
RT-PCR $\operatorname{cyp} 19 a \mathrm{~F}$ & TGGAGATGGTGATCGCCG & $360 \mathrm{bp}$ \\
RT-PCR $\operatorname{cyp} 19 a \mathrm{R}$ & CATGGTGAAGTCCACCAC & \\
RT-qPCR $\operatorname{sox} 9 a \mathrm{~F}$ & GTGCTGAAGGGGTACGACTG & \multirow{2}{*}{$92 \mathrm{bp}$} \\
RT-qPCR $\operatorname{sox} 9 a \mathrm{R}$ & TTCATGGGTCTCTTGACGTG & \\
RT-qPCR $\operatorname{cyp} 19 a \mathrm{~F}$ & AACTGGACCGCATCAACTTC & \multirow{2}{*}{$100 \mathrm{bp}$} \\
RT-qPCR $\operatorname{cyp} 19 a \mathrm{R}$ & ATCACCATCTCCAGCACACA & \\
$18 \mathrm{~s}$ rRNA F & GCTCACCCGCTACTTGGATA & \multirow{2}{*}{$89 \mathrm{bp}$} \\
18s rRNA R & TCTGATAAATGCACGCATCC & \\
\hline
\end{tabular}

\subsection{Quantitative Real Time-PCR}

The quantitative real time-PCR (RT-qPCR) was used to examine changes in sox9a and cyp19a mRNA expression levels in whole or target tissues. For this experiment, $50 \mathrm{mg}$ of the embryos and larval samples were used. The brain, intestine, liver, kidney, heart, and gonadal tissues from ten juveniles, five immature fish and adult fish from each water tank (chosen randomly) were used for total RNA extraction. First of all, DNase I was treated to remove genomic DNA contamination in total RNA. Each $20 \mu \mathrm{L}$ reaction, based on the TOPreal ${ }^{\mathrm{TM}}$ One-step RT-qPCR Kit (Enzynomics co Ltd., Daejeon, Republic of, Korea), produced a $20 \mu \mathrm{L}$ reaction that included the SYBR Green with the final concentration of $0.25 \mu \mathrm{M}$. Both primers had a concentration of $10 \mathrm{pmol} / \mu \mathrm{L}$ each, along with $50 \mathrm{ng} / \mu \mathrm{L}$ RNA extract. The Chromo4 System (Bio-Rad Inc., Contra Costa, CA, USA) was used to measure the reaction with $30 \mathrm{~min}$ at $50^{\circ} \mathrm{C}, 10 \mathrm{~min}$ at $95^{\circ} \mathrm{C}, 40$ cycles of $5 \mathrm{~s}$ at $95^{\circ} \mathrm{C}$ and $30 \mathrm{~s}$ at $60^{\circ} \mathrm{C}$ (with endpoint data collection). All samples were tested in triplicate. The primers used for qRT-PCR was designed using 'primer3' program. The primer sequences are shown in Table 1 . The $2^{-\Delta \mathrm{Ct}}$ method was used for 
the two independent tests of relative $\mathrm{Ct}$ values. $\mathrm{Ct}$ values for reference gene (18s rRNA) were used to normalized expression of target genes.

\subsection{Vitellogenin Assay}

The correlation between VTG and cyp19a relative expression in female fish were investigated in differing water temperatures. Fish ( $>10$ months old, approximately $20 \mathrm{~cm}$ ) were raised from March to October in tanks with different water temperatures $\left(5,8,11\right.$, and $\left.14^{\circ} \mathrm{C}\right)$. To distinguish the sex, the fish were dissected. The protocol for the previous experiment was used for VTG detection [24].

\subsection{Histological Analysis}

The gonadal tissues in adult fish were fixed in $10 \%$ neutral buffered formalin for $48 \mathrm{~h}$, dehydrated in a graded alcohol series, embedded in paraffin wax, and sectioned with a Reichert microtome $(4 \mu \mathrm{m})$. The sections were stained with hematoxylin and eosin (H\&E) and examined using an Olympus Provis AX70 microscope equipped with an Olympus Camedia C70/70 camera.

\subsection{Statistical Analysis}

Statistical analyses were performed in GraphPad Prism (version 8.4.3). Differences between the means were tested by Mann-Whitney or Kruskal-Wallis with post-hoc Dunn's multiple comparison tests were used $(p<0.05)$. All of the data are plotted as mean \pm standard deviation (SD), and the appropriate statistical test values are reported. Pearson correlation analysis was used to examine the correlations between VTG and cyp19a.

\section{Results}

\subsection{Sox9a and Cyp19a mRNA Expression in the Gonadal Tissues with Vitellogenin}

Prior to experiments 1 and 2, the adult fish were investigated for histological analysis of gonadal tissues, RT-PCR for the fragment mRNA sequence (data not shown; GenBank provided in Section 2.2), RT-qPCR of sox9a and cyp19a in gonadal tissues, and the VTG level in blood plasma, which are shown in Figure 2. Histological analysis of male gonadal tissues showed spermatozoa (Spz) and empty spaces after spermatozoa removal at a mature stage (Figure 2A). The testis is an unrestricted lobule that was spermatozoa-filled with spermatocysts, while the female ovarian follicles is filled with yolk globules and vacuoles and encased in zona radiata at the vitellogenesis stage (pre-spawning condition) (Figure 2B). Sox9a was only found in male gonadal tissues while cyp19a was only found in female gonadal tissues (Figure 2B). The male gonadal tissue showed only sox9a with $260 \mathrm{bp}$ PCR product, while the female gonadal tissue showed only cyp $19 a$ with $360 \mathrm{bp}$ PCR product. The comparative expression was very high—sox $9 a$ was expressed at a high level, and cyp $19 a$ was expressed at a very low level (Figure 2D). In females, an average level of plasma VTG was $434.6 \pm 29.18 \mathrm{ng} / \mathrm{mL}$, while in males, the average level of plasma VTG was $1.76 \pm 0.43 \mathrm{ng} / \mathrm{mL}$ (Figure 2E). 
A
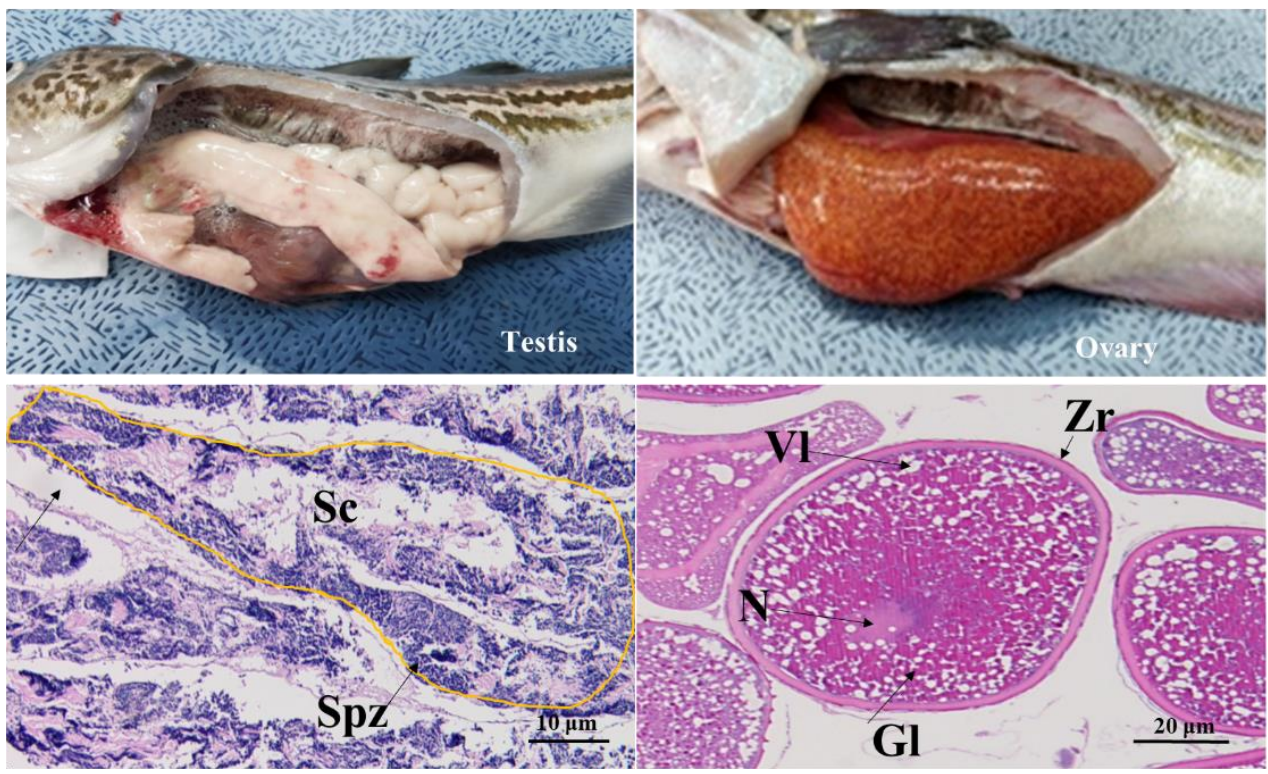

C

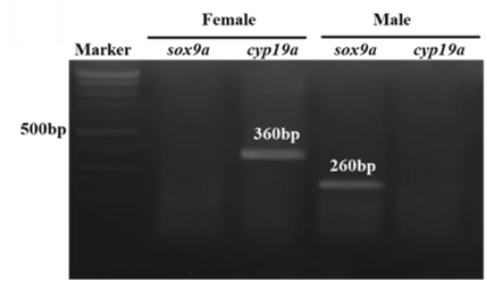

D

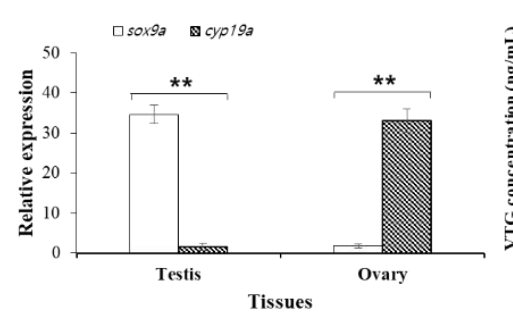

$\mathbf{E}$

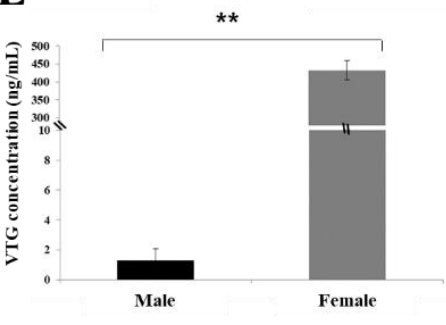

Figure 2. (A) Analysis of the gonadal tissues from mature males and their histological analyses; Spz indicates spermatozoa, Sc indicates spermatocysts (yellow), and the arrows represent empty spaces after spermatozoa removal; (B) Analysis of the gonadal tissues from mature females and their histological analyses. $\mathrm{N}$ indicates nucleus, $\mathrm{Zr}$ indicates zona radiata, $\mathrm{Gl}$ indicates yolk globules, and $\mathrm{Vl}$ indicates vacuoles; (C) Analysis of sox $9 a$ (260 bp) and cyp19a (360 bp) expression in mature male and female gonadal tissues; the results were confirmed by $1.2 \%$ agarose gel. The DNA marker used was 100 bp Plus DNA Ladder (Bioneer, Korea). (D) The relative mRNA expression levels of sox $9 a$ and cyp19a in aldult male and female gonadal tissues. The expression of each sample was relative quantity to the expression of 18s rRNA Values are reported as mean \pm SD of the three experiments; (E) VTG levels in mature male and female blood (by ELISA). * indicates $p<0.05,{ }^{* *}$ indicates $p<0.01$.

\subsection{Sox9a and Cyp19a mRNA Expression in Embryos and Larvae at Different Water Temperatures}

Figure 3A shows the expression of sox $9 a$ and cyp $19 a$ in embryos at different water temperatures. Cyp $19 a$ expression was higher at 5 and $8{ }^{\circ} \mathrm{C}$, while sox $9 a$ expression was higher at 11 and $14^{\circ} \mathrm{C}$. Figure $3 \mathrm{~B}$ shows the expression of sox $9 a$ and cyp $19 a$ in larvae at different water temperatures. Similar to the embryos, cyp $19 a$ expression was higher at 5 and $8{ }^{\circ} \mathrm{C}$, and sox $9 a$ expression was higher at 11 and $14{ }^{\circ} \mathrm{C}$. Figure $3 \mathrm{C}$ shows the increment of sox $9 a$ induction in the embryos compared to cyp $19 a$; sox $9 a$ expression increased with increasing water temperature, and at $14{ }^{\circ} \mathrm{C}$, it was significantly different. Figure 3D shows the increment of sox $9 a$ induction in larvae compared to cyp $19 a$. Similarly, sox $9 a$ expression increased with increasing water temperature, and at $14{ }^{\circ} \mathrm{C}$, it was significantly different. 
A
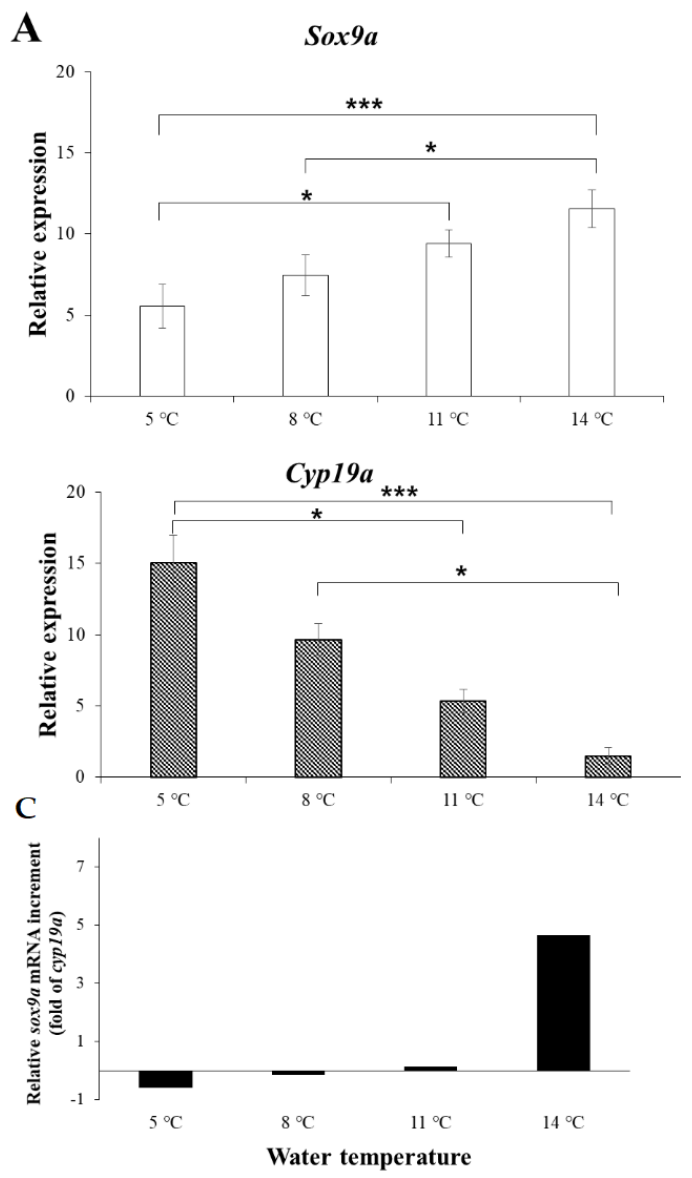

B
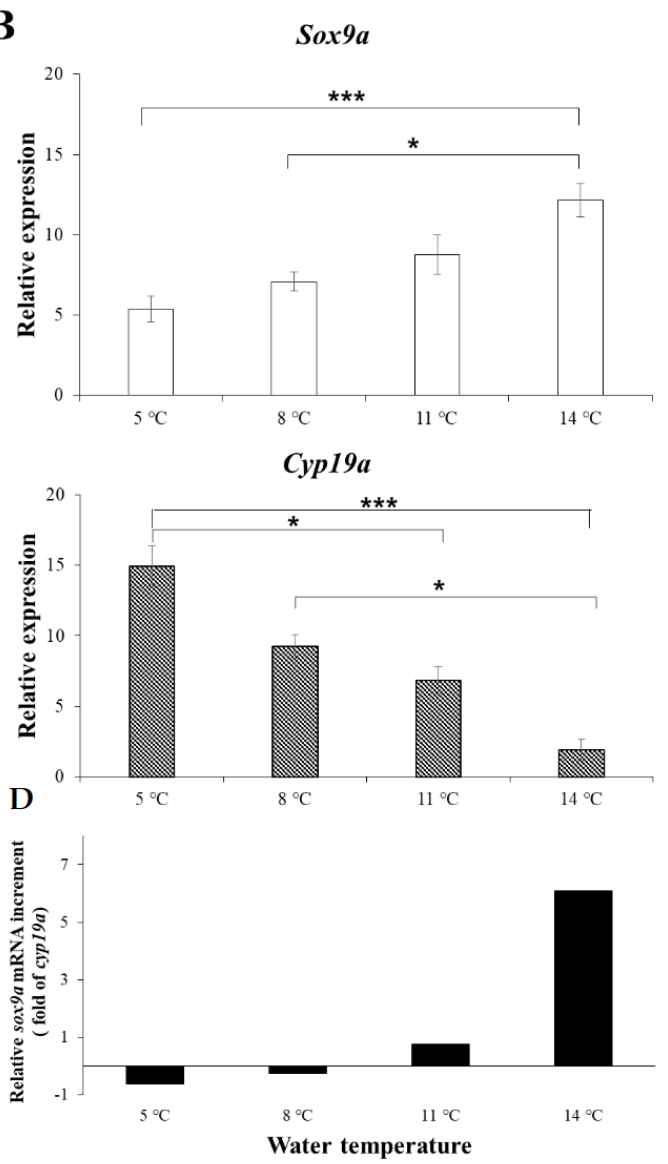

Figure 3. (A) Sox9a and cyp19a mRNA expression levels in the embryos at different water temperatures; (B) Sox $9 a$ and cyp19a mRNA expression levels in the larval samples at different water temperatures; (C) Induction increments of sox $9 a$ at the embryos stage compared to cyp $19 a$; (D) The induction increments of sox $9 a$ at the larvae stage compared to cyp $19 a$. The expression of each sample was relative quantity to the expression of $18 \mathrm{~s}$ rRNA. Values are reported as mean $\pm \mathrm{SD}$ of the three experiments. Mann-Whitney tests were used. ${ }^{*}$ indicates $p<0.05,{ }^{* *}$ indicates $p<0.01,{ }^{* * *}$ indicates $p<0.001$.

\subsection{Distribution of Sox9a and Cyp19a mRNA in Juvenile Fish}

The distribution of sox $9 a$ and cyp $19 a$ mRNA expression was observed in the tissues of juvenile fish. These tissues were from the brain, intestine, liver, kidney, heart, and gonads (testis and ovary). The relative abundance of mRNAs in the walleye pollock tissues showed distinct differences (Figure 4). The cyp19a gene in females was induced at a high level in the brain and gonads and at comparatively lower levels in the intestine, liver, kidney, and heart at $5{ }^{\circ} \mathrm{C}$ (Figure $4 \mathrm{~A}$ ). Similarly, the sox $9 a$ gene in males was induced at a high level in the brain and gonads at $14{ }^{\circ} \mathrm{C}$ (Figure 4B). Table 2 shows the number of individuals with high sox $9 a$ or cyp $19 a$ expression in the different water temperatures. There were more individuals with high cyp $19 a$ expression at 5 to $11^{\circ} \mathrm{C}$, whereas at $14{ }^{\circ} \mathrm{C}$, there were more individuals with high sox $9 a$ expression. 
A

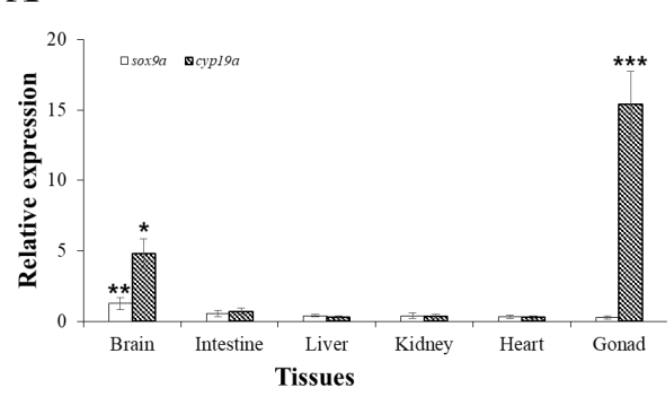

B

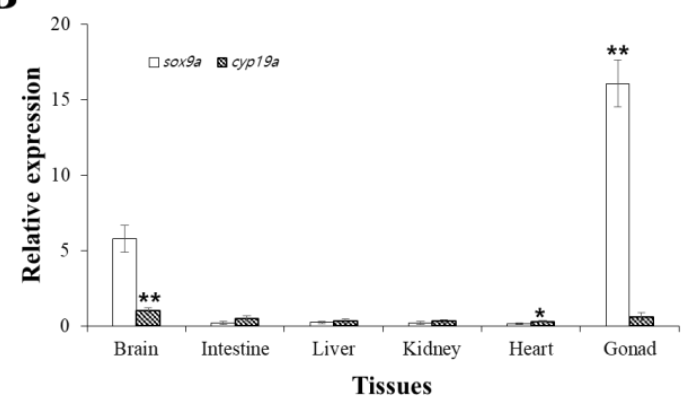

Figure 4. Sox $9 a$ and cyp $19 a$ mRNA expression in the juvenile fish samples. (A) The sample in females when cyp $19 a$ induction is greater than sox $9 a$ induction at $5{ }^{\circ} \mathrm{C}$. (B) The sample in males when sox $9 a$ induction is greater than cyp $19 a$ induction at $14{ }^{\circ} \mathrm{C}$. Kruskal-Wallis with post-hoc Dunn's multiple comparison tests were used. The expression of each sample was relative quantity to the expression of 18 sRNA Values are reported as mean \pm SD of the three experiments. * indicates $p<0.05,{ }^{* *}$ indicates $p<0.01,{ }^{* * *}$ indicates $p<0.001$.

Table 2. Number of individuals based on the expression of sox $9 a$ and cyp $19 a$ in each water temperature. Individuals were counted between higher expression levels for sox $9 a$ and cyp19a. Gene expression was examined by randomly selecting 10 fish from each tank.

\begin{tabular}{ccccc}
\hline Water Temp & \multirow{5}{*}{$\left({ }^{\circ} \mathbf{C}\right)}$, & $\mathbf{8}\left({ }^{\circ} \mathbf{C}\right)$, & $\mathbf{1 1}\left({ }^{\circ} \mathbf{C}\right)$, & $\mathbf{1 4}\left({ }^{\circ} \mathbf{C}\right)$ \\
\hline Gene (Number) & 2 & 4 & 4 & 9 \\
Sox $9 a$ & 8 & 6 & 6 & 1 \\
Total Number & 10 & 10 & 10 & 10 \\
\hline
\end{tabular}

\subsection{Sox9a and Cyp19a mRNA Expression with Vitellogenin in Immature Walleye Pollock}

As mentioned previously (Section 3.1), it was confirmed that in gonads of adult fish, sox9a was only induced in testis, while cyp19a was only induced in ovary. Based on this result, the change in the induction levels of sox $9 a$ and cyp $19 a$ were investigated immature walleye pollock of male testis and female ovary, respectively. In immature fish, the samples were dissected to identify sex via gonadal tissues. Immature walleye pollocks were raised at different temperatures for 10 months, and the induction of sox $9 a$ and cyp $19 a$ mRNA in the gonadal tissues was studied in relation to the VTG induction level in female blood plasma (Figure 5). The water temperature had no significant impact in the sox $9 a$ induction in testis. For cyp $19 a$, there was little difference between 5 and $8{ }^{\circ} \mathrm{C}$, but at $11^{\circ} \mathrm{C}$, the induction level decreased. The cyp19a induction level at $14{ }^{\circ} \mathrm{C}$ was less than half of the value observed at $5^{\circ} \mathrm{C}$ in ovary (Figure 5A). These results indicated that the sox9a induction level was similar at all water temperatures, but cyp19a induction decreased as the water temperature decreased. VTG induction in female blood plasma was $306.63 \pm 28.84 \mathrm{ng} / \mathrm{mL}$ at $5{ }^{\circ} \mathrm{C}, 277.81 \pm 17.57 \mathrm{ng} / \mathrm{mL}$ at $8{ }^{\circ} \mathrm{C}$, $147.23 \pm 18.03 \mathrm{ng} / \mathrm{mL}$ at $11^{\circ} \mathrm{C}$, and $25.68 \pm 6.58 \mathrm{ng} / \mathrm{mL}$ at $14^{\circ} \mathrm{C}$ (Figure $5 \mathrm{~B}$ ). The individual distribution between cyp $19 a$ and VTG were recorded based on different temperatures (Figure 5C). The individuals that were raised at 5 and $8{ }^{\circ} \mathrm{C}$ can be found at the top right. The individuals that were raised at $11{ }^{\circ} \mathrm{C}$ are found in the middle. The individuals raised at $14{ }^{\circ} \mathrm{C}$ formed a group at the bottom left (Figure 5C). The correlation coefficient between cyp 19a and VTG at different temperatures were highest in $5{ }^{\circ} \mathrm{C}$ groups with $\mathrm{R}^{2}=0.89019$ (Figure 5D). There was a tendency for the coefficients to decrease as the temperature increased, with $R^{2}=0.8166$ at $8{ }^{\circ} \mathrm{C}$ (Figure $5 \mathrm{E}$ ), $\mathrm{R}^{2}=0.5257$ at $11^{\circ} \mathrm{C}$ (Figure $5 \mathrm{~F}$ ), and $\mathrm{R}^{2}=0.465$ at $14^{\circ} \mathrm{C}$ (Figure $5 \mathrm{G}$ ). This result showed that VTG was similar patterns to cyp 19a. 
A
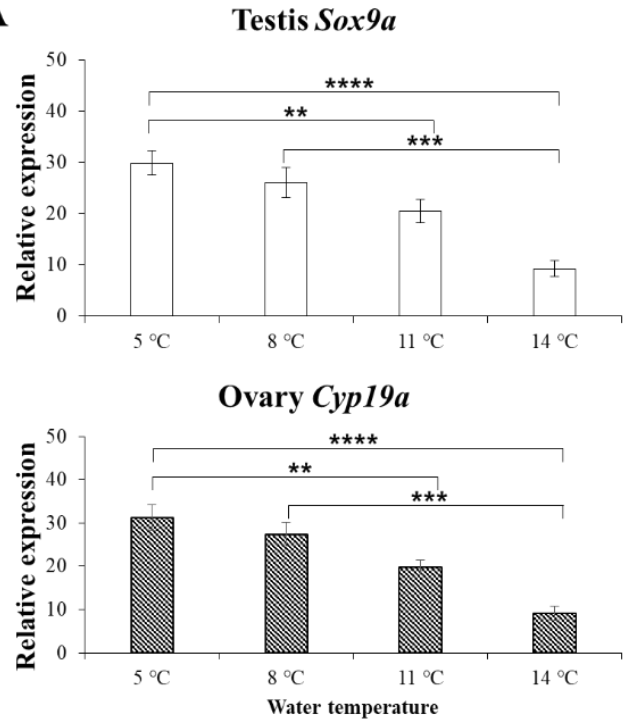

C

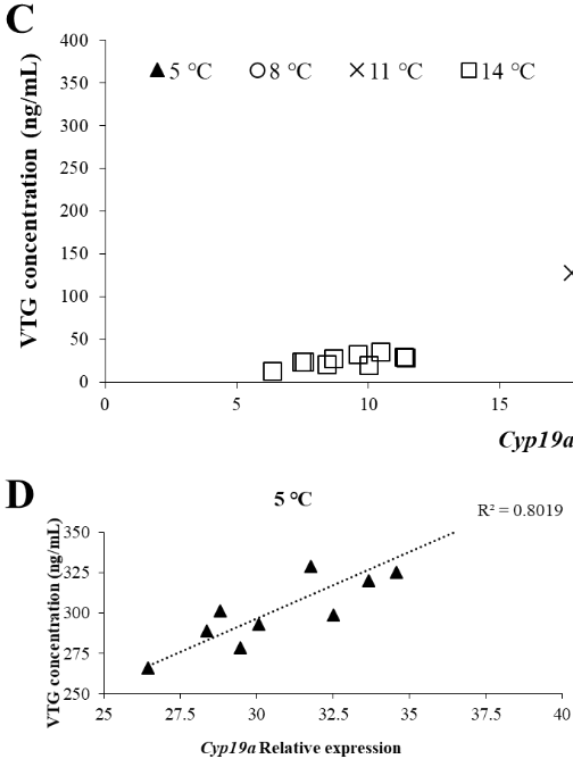

F

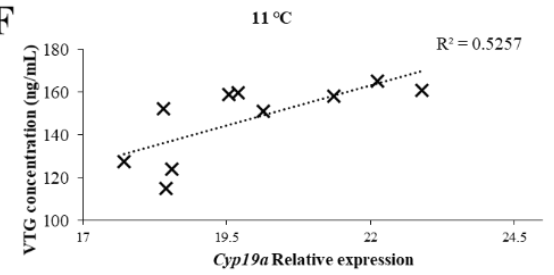

B

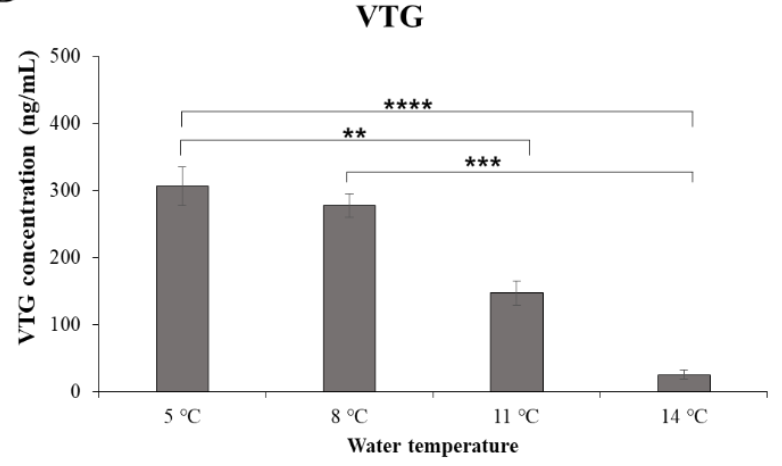

Figure 5. (A) Sox $9 a$ (white bars) and cyp19a (shaded bars) mRNA expression in immature walleye pollock gonadal tissues (testis and ovary) at different water temperatures; (B) VTG levels in female blood. (C) The correlation between cyp19a and VTG at different water temperatures. (D) The correlation between cyp 19a and VTG at $5{ }^{\circ} \mathrm{C}(\mathbf{\Lambda}),\left(\right.$ E) The correlation between cyp19a and VTG at $8{ }^{\circ} \mathrm{C}(\mathrm{O}),(\mathbf{F})$ The correlation between cyp $19 a$ and VTG at $11^{\circ} \mathrm{C}(\mathrm{X})$, and (G) The correlation between cyp $19 a$ and VTG at $14{ }^{\circ} \mathrm{C}(\square)$. The expression of each sample was relative quantity to the expression of $18 \mathrm{~s}$ rRNA. Kruskal-Wallis with post-hoc Dunn's multiple comparison tests were used. Values are reported as mean \pm SD of the three experiments. ${ }^{*}$ indicates $p<0.05,{ }^{* *}$ indicates $p<0.01,{ }^{* * *}$ indicates $p<0.001$, ***** indicates $p<0.0001$. 


\section{Discussion}

In this report, we have described the expression patterns of two sex-related genes, sox9a and cyp $19 a$, in walleye pollock. Consistent with previous experiments, we found sox $9 a$ in mature male walleye pollock gonadal tissues and cyp19a in mature female counterparts. Degani (2014) and Adolfi et al. (2015) suggested that fish sox9a is a sex-related gene that is increased in expression in the testes and decreased in the ovaries [26,27]. Other researchers have studied the expression patterns of these genes zebrafish, medaka, and tilapia gonadal tissues during differentiation [28-30]. In several studies, cyp19a expression was higher in the ovaries, which was similarly observed in other species, including tilapia, black porgy (Acanthopagrus schlegelii), half-smooth tongue-sole (Cynoglossus semilaevis), goldfish (Carassius auratus), and spotted scat (Scatophagus argus) [31-33]. Fish sex determination and differentiation occur during fertilization and in the post-larval stages, and the water temperature plays a vital role in this process (as reported in $>60$ different fish species) [10,13,34-36]. In this study, the expression pattern of sox $9 a$ and cyp $19 a$ were similar during the embryos and larval stages. At $5{ }^{\circ} \mathrm{C}$, cyp $19 a$ expression was the highest, and as the temperature increased, cyp $19 a$ expression decreased. Conversely, sox $9 a$ expression was high between $11-14{ }^{\circ} \mathrm{C}$. This suggests that increases in water temperature are associated with decreased cyp19a expression. Tanaka et al. (2019) raised walleye pollocks in 2, 5, and $8{ }^{\circ} \mathrm{C}$ water and reported higher female ratios in the 2 and $5{ }^{\circ} \mathrm{C}$ treatments and a higher male ratio in the $8{ }^{\circ} \mathrm{C}$ treatment [37]. Fish in our study were raised at $7.5^{\circ} \mathrm{C}$, providing our reasoning for testing at higher temperatures. Despite our use of different water temperatures in juvenile fish, the results were consistent: the female ratio was higher at lower temperatures. To fully investigate the sex ratio, additional studies with more samples are required. Nonetheless, the results of these two independent studies indicate that water temperature is an important factor in walleye pollock sex determination. This is expected, as the sex in walleye pollocks is determined at early developmental stages, and cyp19a affects the sex-determination of females. Sox $9 a$ and cyp $19 a$ expression in the brain and gonadal tissues of juvenile fish were high. This is significant because the aromatization of androgens into estrogens in the brain is necessary for the regulation of several physiological and behavioral processes. In vitro assays of the brains in rats [38], birds, and fish [39] have also shown aromatase activity in many regions. The gonadal tissue investigation showed that high cyp19a expression was associated with female tissues, while high sox $9 a$ expression was associated with male tissues. For most fish, including walleye pollock, the up-regulation of sox $9 a$ leads to differentiation into male testis, whereas the down-regulation of sox $9 a$ leads to differentiation into female ovaries. The opposite patterns have been observed for cyp19a; up-regulation leads to differentiation into ovaries and down-regulation leads to differentiation into testes [21]. These results also show that walleye pollock sex is determined early in development, at the embryo or larval stages. Jorgensen et al. (2008) found that sox $9 a$ in zebrafish is expressed in the undifferentiated gonads, and Nakamoto et al. (2005) and Kobayashi et al. (2008) reported roles for sox9 in the formation of primitive gonadal tissues in medaka and tilapia [31-33]. Similar observations have been reported in zebrafish and black porgy [40].

Immature walleye pollocks (approximately $20-25 \mathrm{~cm}$ in length) were raised in different water temperatures for 10 months, and there were no differences in sox $9 a$ expression in the male gonadal tissues. However, cyp $19 a$ expression significantly decreased at $11^{\circ} \mathrm{C}$ and even more at $14{ }^{\circ} \mathrm{C}$.

Previously, we studied the expression levels of $17 \beta$-estradiol (E2) and VTG at different water temperatures and found that increased water temperature is associated with E2 decreases, which affects the induction of VTG [24]. High temperatures impaired the ovaries in female pejerreyes (Odontesthes bonariensis) by inhibiting the follicle-stimulating hormone receptors (fshr) and plasma E2 levels [41]. Anderson et al. (2012 and 2017) found that suppression of plasma E2 and impairment of downstream VTG is common in female Salmo salar exposed to heat [42,43]. Studies have also shown that cyp19a plays an important and conserved role in the regulation of ovarian E2 [21,44,45]. In this study, VTG induction decreased as the water temperature increased and declined sharply at $14{ }^{\circ} \mathrm{C}$ (similar to cyp 19a). The correlation between cyp19a and VTG is 11 and $14{ }^{\circ} \mathrm{C}$ lower than 5 and $8{ }^{\circ} \mathrm{C}$, which may be related to the vitellogenesis stage during feminization, so further study is needed. 


\section{Conclusions}

This study shows that sex determination and/or differentiation in walleye pollocks occurs in the embryos and post-larval stages. Higher water temperatures tend to result in a higher male ratio, whereas lower water temperatures lead to a higher female ratio. Higher water temperatures also suppress cyp19a expression, which decreases VTG and potentially affects sexual differentiation in female Gadus chalcogrammus.

Author Contributions: Methodology, S.-S.K. and C.-J.L.; Software, S.-S.K.; Formal analysis, S.-S.K. and J.-S.P.; Investigation, H.-K.Y. and J.C.; Resources, D.N.-J.K., S.-G.B., H.-K.Y. and J.C.; Writing-original draft preparation, S.-S.K., D.N.-J.K. and J.-S.P.; Writing—review and editing, S.-S.K. and D.N.-J.K.; Project administration, S.-G.B.; Supervision, J.-S.P.; Funding acquisition, H.-J.L. All authors have read and agreed to the published version of the manuscript.

Funding: Aquaculture Technology Development for species inhabiting the Korean coasts of the East Sea: R2020009.

Acknowledgments: This study was funded by a grant for Aquaculture Technology Development for species inhabiting the Korean coasts of the East Sea (R2020009).

Conflicts of Interest: The authors declare no conflict of interest.

\section{References}

1. Hiatt, T.; Dalton, M.; Felthoven, R.; Fissel, B.; Garber-Yonts, B.; Haynie, A.; Kasperski, S.; Lew, D.; Package, C.; Sepez, J.; et al. Economic status of the ground fish fisheries off Alaska, 2009. In Stock Assessment and Fishery Evaluation Report for the Ground Fish Fisheries of the Gulf of Alaska and Bering Sea/Aleutian Islands Area; North Pacific Fishery Management Council: Anchorage, AK, USA, 2010; p. 254.

2. Bakkala, R.G. Structure and Historical Changes in the Ground Fish Complex of the Eastern Bering Sea; NOAA Technical Report NMFS: Miami, FL, USA; U.S. Department of Commerce: Washington, DC, USA, 1993.

3. Nakatani, T.; Maeda, T. Thermal effect on the development of walleye pollock eggs and their upward speed to the surface. Bull. Jpn. Soc. Sci. Fish. 1984, 50, 937-942. [CrossRef]

4. Graham, C.T.; Harrod, C. Implications of climate change for the fishes of the British Isles. J. Fish Biol. 2009, 74, 1143-1205. [CrossRef]

5. Hinch, S.G.; Cooke, S.J.; Healey, M.C.; Farrell, A.P. Behavioural physiology of fish migrations: Salmon as a model approach Fish Physiology. Behav. Physiol. Fish. 2005, 24, 239-295.

6. Hari, R.E.; Livingstone, D.M.; Siber, R.; Burkhardt-Holm, P.; Herbert, G. Consequences of climatic change for water temperature and brown trout populations in Alpine rivers and streams Glob. Chang. Biol. 2006, 12, 10-26. [CrossRef]

7. Jobling, M. Temperature and growth: Modulation of growth rate via temperature change. In Global Warming: Implications for Freshwater and Marine Fish; Wood, C.M., McDonald, D.G., Eds.; Cambridge University Press: Cambridge, UK, 1997; pp. 225-253.

8. Salinger, D.H.; Anderson, J.J. Effects of water temperature and flow on adult salmon migration swim speed and delay. Trans. Am. Fish. Soc. 2006, 135, 188-199. [CrossRef]

9. Sponaugle, S.; Cowen, R.K. Larval supply and patterns of recruitment for two Caribbean reef fishes, Stegastes partitus and Acanthurus bahianus. Mar. Freshw. Res. 1996, 47, 433-447. [CrossRef]

10. Devlin, R.H.; Nagahama, Y. Sex determination and sex differentiation in fish: An overview of genetic, physiological, and environmental influences. Aquaculture 2002, 208, 191-364. [CrossRef]

11. Baroiller, J.F.; D'Cotta, H.; Saillant, E. Environmental effects on fish sex determination and differentiation. Sex. Dev. 2009, 3, 118-135. [CrossRef]

12. Baroiller, J.F.; D'Cotta, H. Environment and sex determination in farmed fish. Comp. Biochem. Physiol. C Toxicol. Pharmacol. 2001, 130, 399-409. [CrossRef]

13. Baroiller, J.F.; Guiguen, Y. Endocrine and environmental aspects of sex differentiation in gonochoristic fish. EXS 2001, 177, 201.

14. Godwin, J. Social determination of sex in reef fishes. Semin. Cell. Dev. Biol. 2009, 20, 264-270. [CrossRef] [PubMed]

15. Conover, D.O.; Heins, S.W. Adaptive variation in environmental and genetic sex determination in a fish. Nature 1987, 326, 496-498. [CrossRef] [PubMed] 
16. Koopman, P.; Gubbay, J.; Vivian, N.; Goodfellow, P.; Lovell-Badge, R. Male development of chromosomally female mice transgenic for sry. Nature 1991, 351, 117-121. [CrossRef] [PubMed]

17. Kent, J.; Wheatley, S.C.; Andrews, J.E.; Sinclair, A.H.; Koopman, P.A. Male-specific role for sox9 in vertebrate sex determination. Development 1996, 122, 2813-2822. [PubMed]

18. Smith, C.A.; Roeszler, K.N.; Ohnesorg, T.; Cummins, D.M.; Farlie, P.G.; Doran, T.J.; Sinclair, A.H. The avian Z-linked gene dmrt1 is required for male sex determination in the chicken. Nature 2009, 461, 267-271. [CrossRef]

19. Heule, C.; Salzburger, W.; Böhne. Genetics of sexual development: An evolutionary playground for fish. Genetics 2014, 196, 579-591. [CrossRef]

20. Piferrer, F.; Ribas, L.; Díaz, N. Genomic approaches to study genetic and environmental influences on fish sex determination and differentiation. Mar. Biotechnol. 2012, 14, 591-604. [CrossRef]

21. Guiguen, Y.; Fostier, A.; Piferrer, F.; Chang, C.-F. Ovarian aromatase and estrogens: A pivotal role for gonadal sex differentiation and sex change in fish. Gen. Comp. Endocrinol. 2010, 165, 352-366. [CrossRef] [PubMed]

22. Wang, D.-S.; Kobayashi, T.; Zhou, L.-Y.; Paul-Prasanth, B.; Ijiri, S.; Sakai, F.; Okubo, K.; Morohashi, K.I.; Nagahama, Y. Foxl2 up-regulates aromatase gene transcription in a female-specific manner by binding to the promoter as well as interacting with Ad4 binding protein/steroidogenic factor 1. Mol. Endocrinol. 2007, 21, 712-725. [CrossRef]

23. Simpson, E.R.; Mahendroo, M.S.; Means, G.D.; Kilgore, M.W.; Hinshelwood, M.M.; Graham-Lorence, S.; Amarneh, B.; Ito, Y.; Fisher, C.R.; Michael, M.D.; et al. Aromatase cytochrome P450, the enzyme responsible for estrogen biosynthesis. Endocr. Rev. 1997, 15, 342-355.

24. Kim, S.S.; So, J.H.; Maeng, C.H.; Kim, N.-J.D.; Lee, C.J.; Ma, Y.; Yoo, H.K.; Choi, J.; Byun, S.G.; Lim, H.J.; et al. The influence of water temperature on the induction of vitellogenin in walleye pollock Gadus chalcogrammus. Aquaculture 2019, 511, 634195. [CrossRef]

25. Sole, M.; Porte, C.; Barcelo, D. Analysis of the estrogenic activity of sewage treatment works and receiving waters using vitellogenin induction in fish as a biomarker. Trac Trend Anal. Chem. 2001, 20, 518-525. [CrossRef]

26. Degani, G. Expression of SOX3 and SOX9 genes in gonads of blue gourami. Adv. Biol. Chem. 2014, 4, 322-330. [CrossRef]

27. Adolfi, M.C.; Carreira, A.C.; Jesus, L.W.; Bogerd, J.; Funes, R.M.; Schartl, M.; Sogayar, M.C.; Borella, M.I. Molecular cloning and expression analysis of dmrt1 and sox9 during gonad development and male reproductive cycle in the lambari fish, Astyanax altiparanae. Reprod. Biol. Endocrinol. 2015, 13, 2. [CrossRef]

28. Nakamoto, M.; Suzuki, A.; Matsuda, M.; Nagahama, Y.; Shibata, N. Testicular type Sox9 is not involved in sex determination but might be in the development of testicular structures in the medaka, Oryzias latipes. Biochem. Biophys. Res. Commun. 2005, 333, 729-736. [CrossRef]

29. Jorgensen, A.; Morthorst, J.E.; Andersen, O.; Rasmussen, L.J.; Bjerregaard, P. Expression profiles for six zebrafish genes during gonadal sex differentiation. Reprod. Biol. Endocrinol. 2008, 6, 25. [CrossRef]

30. Kobayashi, T.; Kajiura-Kobayashi, H.; Guan, G.; Nagahama, Y. Sexual dimorphic expression of DMRT1 and Sox9a during gonadal differentiation and hormone-induced sex reversal in the teleost fish Nile tilapia (Oreochromis niloticus). Dev. Dyn. 2008, 237, 297-306. [CrossRef]

31. Deng, S.P.; Chen, S.L.; Xu, J.Y.; Liu, B.W. Molecular cloning, characterization and expression analysis of gonadal P450 aromatase in the half-smooth tongue-sole, Cynoglossus semilaevis. Aquaculture 2009, 287, 211-218. [CrossRef]

32. Chen, X.W.; Jiang, S.; Gu, Y.F.; Shi, Z.Y. Molecular characterization and expression of cyp19a gene in Carassius auratus. J. Fish Biol. 2014, 85, 516-522. [CrossRef]

33. Liu, H.; Mu, X.; Gui, L.; Su, M.; Li, H.; Zhang, G.; Liu, Z.; Zhang, J. Characterization and gonadal expression of FOXL2 relative to Cyp19a genes in spotted scat Scatophagus argus. Gene 2015, 561, 6-14. [CrossRef]

34. Ospina-Alvarez, N.; Piferrer, F. Temperature-dependent sex determination in fish revisited: Prevalence, a single sex ratio response pattern, and possible effects of climate change. PLoS ONE 2008, 3, 2837. [CrossRef]

35. Conover, D.; Kynard, B. Environmental sex determination: Interaction of temperature and genotype in a fish. Science 1981, 213, 31. [CrossRef] [PubMed]

36. Baroiller, J.F.; Guiguen, Y.; Fostier, A. Endocrine and environmental aspects of sex differentiation in fish. Cell. Mol. Life Sci. 1999, 55, 910-931. [CrossRef] 
37. Tanaka, H.; Nakagawa, T.; Yokota, T.; Chimura, M.; Yamashita, Y.; Funamoto, T. Effects of spawning temperature on the reproductive characteristics of walleye pollock Gadus chalcogrammus. Fish. Sci. 2019, 85, 901-911. [CrossRef]

38. Roselli, C.E. Distribution and regulation of aromatase activity in the rat hypothalamus and limbic system. Endocrinology 1985, 117, 2471-2477. [CrossRef]

39. Gelinas, D.; Callard, G.V. Immunolocalization of aromatase- and androgen receptor-positive neurons in the goldfish brain. Gen. Comp. Endocrinol. 1997, 106, 155-168. [CrossRef] [PubMed]

40. Rodriguez-Mari, A.; Yan, Y.L.; Bremiller, R.A.; Wilson, C.; Canestro, C.; Postlethwait, J.H. Characterization and expression pattern of zebrafish Anti-Mullerian hormone (Amh) relative to sox9a, sox9b, and cyp19a1a, during gonad development. Gene Expr. Patterns 2005, 5, 655-667. [CrossRef] [PubMed]

41. Soria, F.N.; Strüssmann, C.A.; Miranda, L.A. High water temperatures impair the reproductive ability of the pejerrey fish Odontesthes bonariensis: Effects on the hypophyseal-gonadal axis. Physiol. Biochem. Zool. 2008, 81, 898-905. [CrossRef]

42. Anderson, K.; Pankhurst, N.W.; King, H.; Elizur, A. Effect of thermal challenge on the expression of genes involved in ovarian steroidogenesis in Tasmanian Atlantic salmon (Salmo salar). Aquaculture 2017, 479, 474-478. [CrossRef]

43. Anderson, K.; Swanson, P.; Pankhurst, N.; King, H.; Elizur, A. Effect of thermal challenge on plasma gonadotropin levels and ovarian steroidogenesis in female maiden and repeat spawning Tasmanian Atlantic salmon (Salmo salar). Aquaculture 2012, 334-337, 205-212. [CrossRef]

44. Luckenbach, J.A.; Early, L.W.; Rowe, A.H.; Borski, R.J.; Daniels, H.V.; Godwin, J. Aromatase cytochrome P450: Cloning, intron variation, and ontogeny of gene expression in southern flounder (Paralichthys lethostigma). J. Exp. Zool. A 2005, 303, 643-656. [CrossRef] [PubMed]

45. Matsuoka, M.P.; Nes, V.S.; Andersen, O.; Benfey, T.J.; Reith, M. Real-time PCR analysis of ovary- and brain-type aromatase gene expression during Atlantic halibut (Hippoglossus hippoglossus) development. Comp. Biochem. Physiol. B 2006, 144, 128-135. [CrossRef] [PubMed]

(C) 2020 by the authors. Licensee MDPI, Basel, Switzerland. This article is an open access article distributed under the terms and conditions of the Creative Commons Attribution (CC BY) license (http://creativecommons.org/licenses/by/4.0/). 